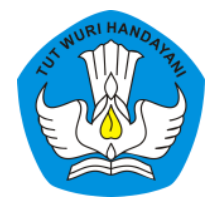

Page: 907-934

\title{
EFEKTIFITAS PENGGUNAAN MEDIA PEMBELAJARAN MENARA RODA UNTUK MEMBERDAYAKAN PESERTA DIDIK BERKEBUTUHAN KHUSUS
}

\author{
Prayitno \\ Sekolah Dasar Negeri Tunjung 1 Burneh, Bangkalan, Jawa Timur, Indonesia \\ Contributor Email: suramadu.prayitno3@gmail.com
}

Received: Feb 15, 2021

Accepted: Oct 6, 2021

Published: Nov 30, 2021

Article Url: https://ojsdikdas.kemdikbud.go.id/index.php/didaktika/article/view/359

\begin{abstract}
Students with special needs at Tunjung 1 Public Elementary School have limited social interaction, verbal and emotional communication. Need to be trained in society to be given good opportunities, through special education services. Learning facilities that attract his attention need to be created, in order to help him socialize, play together without being disturbed, and can improve his academic achievement. For this reason, the writer created the "Wheel Tower". The goal is to empower students with special needs children with autism and improve academic achievement, especially in number patterns. These media are designed to be used jointly, and individually. This media is in the form of stacked wheels that are arranged together, forming a flat shape (square, triangle, rectangle) from the large to the small one that resembles a tower. The shape of the tower shows a number pattern from small to large. From the learning process and results the use of "wheel towers" can empower students with special needs autistic children with regular children and can improve their academic achievement, especially in number patterns.
\end{abstract}

Keywords: Autism; Medium; Wheel Tower. 


\begin{abstract}
Abstrak
Peserta didik berkebutuhan khusus di Sekolah Dasar Negeri Tunjung 1 memiliki keterbatasan berinteraksi sosial, berkomunikasi verbal dan emosional. Perlu dilatih bermasyarakat diberi kesempatan yang baik, melalui layanan pendidikan secara khusus. Sarana pembelajaran yang menarik perhatiannya perlu diciptakan agar dapat membantunya bersosialisasi, bermain bersama tanpa merasa terganggu, dan dapat meningkatkan prestasi akademiknya. Untuk itu penulis menciptakan "Menara Roda". Tujuannya memberdayakan peserta didik berkebutuhan khusus anak autis dan meningkatkan prestasi akademik khususnya pada pola bilangan. Media ini dirancang untuk digunakan secara bersama-sama,, tetapi juga dapat digunakan secara individu. Media ini berupa rodaroda bertumpuk yang disusun secara bersama, membentuk bangun datar (persegi, segitiga, persegi panjang) dari yang bentuknya besar ke yang kecil menyerupai menara. Bentuk menara tersebut menunjukkan pola bilangan dari kecil ke besar. Dari proses dan hasil pembelajaran penggunaan "menara roda" dapat memberdayakan peserta didik berkhebutuhan khusus anak autis dengan anak reguler dan dapat meningkatkan prestasi akademiknya khususnya pada pola bilangan.
\end{abstract}

Kata Kunci: Autis; Media; Menara Roda.

\title{
A. Pendahuluan
}

Pendidikan inklusif di abad ke 21 dan di era revolisi industri 4.0 sudah menjadi keharusan. Pembukaan Undang-Undang Dasar Negara Republik Indonesia tahun 1945 mengamanatkan dengan tegas bahwa tujuan negara adalah "mencerdaskan kehidupan bangsa". Selanjutnya diterangkan pada pasal 31 ayat (1) Setiap warga negara berhak mendapatkan pendidikan; (2) Setiap warga negara wajib mengikuti pendidikan dasar dan pemerintah wajib membiayainya.

Dalam pasal 26 ayat 1 juga dijelaskan bahwa "Yang menjadi warga negara ialah orang-orang bangsa Indonesia asli dan orang-orang bangsa lain yang disahkan dengan undang-undang sebagai warga negara". Melihat dari definisi tersebut bahwa semua orang asli maupun orang bangsa lain yang ditetapkan dengan undang-undang yang berada di wilayah Indonesia maupun di wilayah negara lain tidak ada pengecualian. Baik itu sehat jasmani maupun yang sakit, sehat rohani maupun tidak sehat rohaninya, putra maupun putri, tua ataupun muda, kaya miskin, putih maupun hitam, rakyat jelata maupun kaum bangsawan, normal maupun disabilitas adalah semua warga negara Indonesia tanpa terkecuali. 
Semua warga negara tersebut berhak untuk mendapatkan pendidikan. Sekurang-kurangnya wajib mendapatkan pendidikan dasar (Sekolah Dasar dan Sekolah Menengah Pertama).

Pasal 28B ayat 2 Undang-Undang Dasar 1945 menyatakan bahwa, "Setiap anak berhak atas kelangsungan hidup, tumbuh dan berkembang serta berhak atas perlindungan dari kekerasan dan diskriminasi". Anak dilahirkan dari rahim ibunya dalam keadaan suci tidak membawa noda. Semua orang tua mengharapkan kelahiran anaknya dalam keadaan normal tidak ada kecacatan apapun. Namun ada kalanya anak terlahir dengan keadaan berkebutuhan khusus (disabilitas). Anak merupakan anugerah Tuhan Yang Maha Esa. Tidak ada orang tua yang normal, yang menolak kelahiran anaknya baik itu normal maupun disabilitas.

Banyak pula orang tua yang merasa malu memiliki anak berkebutuhan khusus. Sehingga cenderung menyembunyikan kekurangan atau hambatan yang dimiliki oleh putra-putrinya. Pada hal ini tidak perlu dilakuka, karena mungkin Tuhan Yang Maha Esa memiliki rencana unggul bagi umatnya ini. Selain itu, pula dengan menyembunyikan hambatan ini akan memengaruhi jenis pelayanan, bimbingan yang dibutuhkan oleh anak, serta tindakan yang diberikan oleh guru di sekolah. Jika hal ini dilakukan oleh orang tua peserta didik, guru tidak boleh memaksanya untuk memberikan informasi yang sejelas-jelasnya, karena sudah menjadi ranah pribadi orang tersebut. Di sini guru harus mampu menggali informasi secara arif dan bijaksana, serta menyimpan rapat-rapat jika informasi ini tidak dikehendaki olehnya. Karena jika ini dilanggar, akan mengurangi rasa percaya kepada sekolah, menambah tumpukan penderitaan, serta mungkin memberikan sumbangan tambahan rasa rendah diri padanya. Karena permasalahan ini maka dalam penelitian ini anak berkebutuhan khusus yang menjadi subjek penelitian ditulis dengan inisial. Tujuannya adalah menjaga marwah kepercayaan, tanpa mengurangi derajad keunggulan, sehingga juga mampu memberikan sumbangsih yang bermanfaat bagi guru, orang tua, sekolah yang memiliki problem yang serupa, demi terwujudnya anak bangsa yang merdeka, mandiri, cerdas berkarakter. 
Normal atau disabilitas adalah warga negara Indonesia. Maka keduaduanya berhak atas pendidikan tanpa ada diskriminasi. Namun, kenyataan di lapangan masih banyak diskriminasi terhadap pelayanan pendidikan. Terutama pada anak-anak berkebutuhan khusus. Sebenarnya sudah ada usaha yang dilakukan oleh pemerintah maupun swasta dan masyarakat dalam melayani anak-anak berkebutuhan khusus ini yaitu dengan mendirikan Sekolah Luar Biasa (SLB). Tetapi rata-rata jumlah SLB di setiap kabupaten/ kota tidak lebih dari hitungan jari tangan. Itu pun letaknya di ibu kota kabupaten. Sementara luas wilayahnya sangat luas, yang mana dimungkinkan dari keluasan tersebut pasti ada anak disabilitas, yang selanjutnya disebut anak berkebutuhan khusus (ABK). Maka sangatlah kecil SLB tersebut dapat menjangkau seluruh anak berkebutuhan khusus yang ada di wilayah tersebut. Sehingga terjadi kesenjangan pelayanan pendidikan dengan berbagai kelompok, rentan terhadap diskriminasi dan eksklusi.

Anak berkebutuhan khusus menurut Satyadi (2015: 37) merupakan anak yang memang secara signifikan berbeda dalam beberapa dimensi yang penting dari fungsi kemanusiaannya. Manusia adalah makhluk sosial. Maka dari itu insan manusia harus dapat hidup berdampingan dengan indah antara satu dengan lainnya, tanpa membedakan latar belakang, status sosial, maupun lainnya. Untuk dapat hidup berdampingan bagi peserta didik perlu diajarkan. Sekolah adalah miniatur kehidupan. Di sinilah semua karakter berkembang dengan baik. Suyanto (2012; 49) menerangkan bahwa karakter adalah cara berpikir dan berperilaku yang menjadi ciri khas tiap individu untuk hidup dan bekerjasama, baik dalam lingkup keluarga, masyarakat, bangsa dan negara.

Widyawati (2015: 98) mengatakan anak berkebutuhan khusus yang perlu penanganan khusus tidak harus belajar di sekolah khusus, mereka bisa saja disekolahkan di sekolah umum bersama anak normal lainnya. Djahiri (1996: 18) mengatakan bahwa (1) setiap orang lahir dengan membawa kodrat anugerah dan amanah Illahi (yang bermakna titipan untuk dibina/dipelihara, dikembangkan dan dibermaknakan sebagaimana ketentuan-Nya), (2) bahwa potensi diri tersebut adalah sama (jenis dan wujudnya) pada setiap orang, serta potensial namun sarat akan keterbatasan. Wujud dan jenis yang sama itu ialah 
antara lain wujud ragawi dan rokhaniah serta jiwa (nyawa) yang selanjutnya tergantung pada yang bersangkutan, orang tua, saudara serta lingkungan belajarnya.

Pembelajaran pada pendidikan di abad ke-21 dan menuju era revolusi industri 4.0 harus dapat melatihkan peserta didik yang mampu berpikir kreatif, kritis, kolaboratif, dan komunikatif. Diharapkan sekurangkurangnya dari proses pembelajaran tersebut, kelak akan tercipta insan Indonesia yang literat, kompeten, dan berkarakter tanpa terkecuali baik anak normal maupun yang berkebutuhan khusus.

Insan Indonesia sebagaimana di atas dapat terwujud jika dilatihkan. Salah satu latihannya adalah membentuk miniatur kehidupan di sekolah. Dalam kehidupan sehari-hari, isi masyarakat itu beragam macam bentuknya. Baik status, warna kulit, suku bangsa, bangsa, dan pemikiran akan mewujudkan pola kehidupan yang harmonis. Tetapi jika sebuah pola kehidupan dikelompokkan berdasarkan statusnya akan terjadi komunikasi yang itu-itu saja. Misalnya anak dengan ketunaan tuna wicara dikumpulkan dengan anak yang tuna wicara dia akan dapat berkomunikasi dengan baik. Tetapi apakah anak yang tuna wicara tersebut dalam kehidupan bermasyarakat, mereka hanya akan bersama dengan teman yang sama. Tentu tidak. Mereka akan bergaul dengan teman-temannya yang bukan anak berkebutuhan khusus yang selanjutnya disebut anak reguler. Demikian juga anak-anak reguler juga akan bergaul dengan temannya, anak berkebutuhan khusus.

Inklusif (pelibatan semua) menurut Brower (2010: 3) saat ini menjadi istilah yang lazim dalam lingkungan pendidikan dan memunculkan tanggapan yang posistif dan negatif, baik dari kalangan orang tua maupun pengajar. Inklusif dapat menjadi sebuah pengalaman positif bagi murid autis dan murid berkebutuhan khusus lainnya apabila diberdayakan secara sesuai, pihak sekolah siap menjalaninya setelah melalui pelatihan, dan seluruh komponen sekolah telah memiliki pemahaman terhadap hal ini.

Dalam Permendiknas No. 70 tahun 2010 disebutkan bahwa pendidikan inklusif adalah sistem penyelenggaraan pendidikan yang memberikan kesempatan kepada semua peserta didik berkelainan dan memiliki potensi kecerdasan dan/ atau bakat istimewa untuk mengikuti pendidikan atau pembelajaran dalam lingkungan pendidikan secara bersama-sama dengan peserta didik umumnya. Pendidikan 
inklusif merujuk pada persamaan hak setiap anak untuk mendapatkan pendidikan yang layak dan seutuhnya. Selama ini masih banyak anak berkebutuhan khusus yang harus disekolahkan pada sekolah khusus pula. Pendidikan inklusif merupakan perkembangan terkini dari model pendidikan bagi anak berkebutuhan khusus.

Sekolah Dasar Negeri Tunjung 1 ditunjuk oleh Dinas Pendidikan Kabupaten Bangkalan sejak tahun pelajaran 2010/2011 sebagai sekolah penyelenggara pendidikan inklusif. Berdasarkan hal tersebut sekolah ini wajib menerima peserta didik anak berkebutuhan khusus. Beberapa peserta didik anak berkebutuhan khusus yang telah masuk di sekolah ini antara lain peserta didik dengan ketunaan tuna grahita, tuna laras, tuna daksa, lemah belajar, dan autis. Sejak saat itu sampai sekarang Sekolah Dasar Negeri Tunjung 1 telah meluluskan peserta didik anak berkebutuhan khusus sebanyak 2 orang dengan ketunaan autis (inisial: Asa) dan tuna grahita (inisial: Zul). Selain itu, ada siswa yang tidak berhasil menyelesaikan pendidikannya yakni satu siswi tuna laras mengundurkan diri dari sekolah ini (inisial Siti).

Dalam hal pembelajaran peserta didik yang berada di Sekolah Dasar Negeri Tunjung 1 ini sebagai sekolah penyelenggara pendidikan inklusif, harus menerima pembelajaran yang sama sesuai dengan karakteristik peserta didik yang berbeda-beda tersebut. Pembelajaran dilaksanakan di kelas reguler karena sekolah belum memiliki ruang kelas khusus. Selain itu, sesuai dengan nafas pendidikan inklusif tidak memerlukan kelas khusus. Tenaga pendidik yang bertugas adalah semua guru kelas yang memiliki peserta didik anak berkebutuhan khusus dibantu oleh beberapa orang guru pendamping khusus (GPK) yang ditunjuk berdasarkam musyawarah dewan guru sesuai dengan kesiapan dan kemampuan guru tersebut. Artinya, di sini seorang guru yang siap menjadi guru pendamping khusus secara mental dan emosional, juga sesuai kemampuan mendampingi peserta didik sesuai dengan ketunaan, serta kompetensi guru tersebut. Guru pendamping khusus sebelumnya telah mendapatkan pelatihan terlebih dahulu.

Selama lima tahun ditugasi menjadi guru pendamping khusus, dengan bekal pengetahuan yang sangat minim, membuat penulis tertantang untuk melaksanakan tugas tersebut. Meskipun telah berbekal diklat 
kompensatoris dari Dinas Pendidikan dan Kebudayaan Provinsi Jawa Timur, tugas ini tetap menjadi beban moral yang harus dijalankan. Brower (2010:33) mengatakan tidak ada situasi yang lebih membuat frustasi dari pada ketika seorang murid selalu berada di luar kelompok, selalu menjadi orang terakhir yang dipilih, seseorang yang makan sendirian di kantin, orang yang terisolasi di taman bermain. Kewajiban kitalah untuk bertanggung jawab dalam memupuk persahabatan dan memungkinkan terjalinnya hubungan sebagai usaha untuk mengurangi kerentanan murid autis.

Dalam memberikan pelayanan pembelajaran antara peserta didik anak berkebutuhan khusus dengan ketunaan tuna daksa berbeda dengan anak autis. Hal ini karena yang dibutuhkan atau jenis kekurangan serta kemampuannya berbeda. Di sini guru pendamping khusus dituntut untuk selalu berkoordinasi dengan guru kelasnya. Dalam hal melaksanakan pendampingan adalah pada saat guru pendamping khusus tersebut memiliki jam kosong. Misalnya, pada saat pelajaran olah raga, pendidikan agama, dan muatan lokal, dan pada waktu-waktu tertentu secara insidentil pada saat terdapat permasalahan secara mendadak pada peserta didik anak berkebutuhan khusus. Jadi dalam satu minggu, sekurang-kurangnya, guru pendamping khusus mendampingi peserta didik ABK dan guru kelas dalam memberikan layanan pembelajaran empat kali. Tempat, bentuk pelayanan disesuaikan dengan situasi dan kondisi. Misalnya di dalam kelas reguler saat kegiatan pembelajaran berlangsung; pada tempat khusus secara individi; dan di mana saja saat peserta didik anak berkebutuhan khusus berada. Salah satu peserta didik anak berkebutuhan khusus di Sekolah Dasar Negeri Tunjung 1 ini yakni 2 orang autis bernama Afa dan Muf (inisial). Afa kelas IVA, sedangkan Muf kelas IA. Kedua peserta didik tersebut menjadi peserta didik pendampingan penulis.

Afa yang menjadi sasaran dalam penelitian ini, dalam perilakunya sehari-hari memiliki kebiasaan sebagai berikut. (1) Meracau dengan bahasa yang tidak dapat dimengerti orang lain, dan bicara bukan untuk komunikasi, hanya dibunyikan tanpa makna; (2) Jika menginginkan sesuatu, ia menarik tangan atau sesuatu yang terdekat dan mengharapkan orang tersebut melakukan untuknya; 

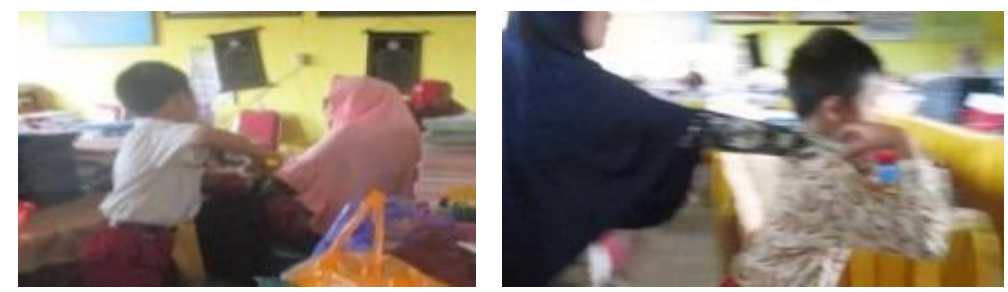

(3) Menolak atau menghindari tatapan muka dengan orang lain. Selain itu dia tidak suka jika di foto atau direkam, dan jika dia didekati malah menjauh;

(4) Terlihat berperilaku yang berlebihan antara lain hiperaktif motorik, seperti tidak bisa diam, lari ke sana-sini tidak terarah, melompat-lompat, berputar-putar, memukul-mukul benda tertentu yang ada di dekatnya; dan (5) Sering mengamuk tak terkendali terutama bila tidak mendapatkan apa yang diinginkan, bahkan bisa menjadi agresif dan destruktif. Dari kebiasaan atau gejala sebagaimana tersebut di atas, Afa mengalami gangguan pada bidang komunikasi verbal, nonverbal, perilaku, dan perasaan atau emosi.
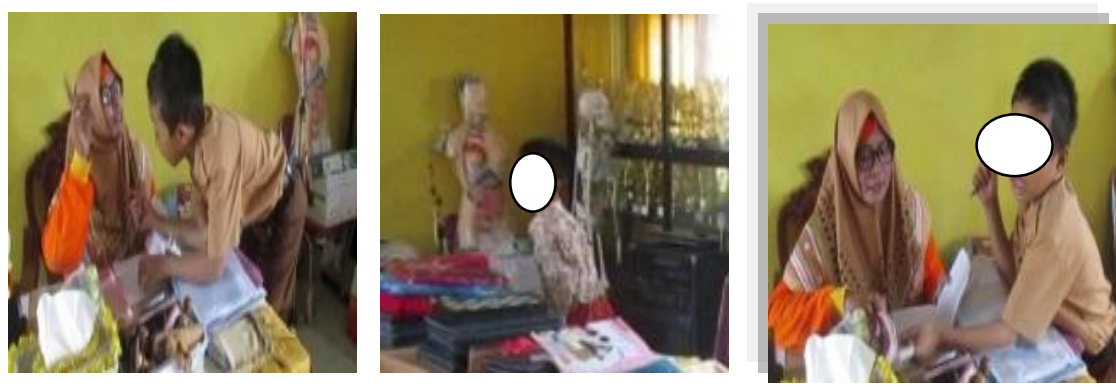

Derajat autis (Mudjito, dkk; 2014: 13) sejalan dengan pengklasifikasian yang didasarkan pada fungsi kecerdasan penyandang autis, yang dapat dikategorikan dalam 3 tingkatan autis, yaitu fungsi keserdasan rendah (low functioning intelligence), fungsi kecerdasan menengah (medium functioning intelligence), dan fungsi kecerdasan tinggi (high functioning intelligence).

Autis merupakan salah satu kelompok gangguan pada anak yang ditandai dengan munculnya gangguan dan keterlambatan dalam bidang kognitif, komunikasi, ketertarikan pada interaksi sosial dan perilakunya. Menurut Depdiknas pada tahun 2002, autisme adalah suatu perkembangan yang kompleks menyangkut komunikasi, interaksi sosial, dan aktivitas imajinasi. Karakteristik khusus autisme antara lain sangat suka menyendiri dan 
miskin kemampuan respon sosial yang berlebihan, terhadap suatu rutinitas atau pola tetap, memiliki ingatan yang kuat, dan perkembangan bahasa yang lambat (Worth, 2005: 1). Selain itu Veskarisyanti (2008: 16) juga menyatakan bahwa autisme memang merupakan kelainan perilaku yang penderitanya hanya tertarik pada aktivitas mentalnya sendiri.

Dalam hal ini Afa masuk dalam kategori fungsi kecerdasan menengah. Ditandai dengan kekurangan dan keterbatasan dalam berinteraksi serta dalam memberikan respon secara sosial, dan keterbatasan yang nyata dalam beberapa hal berkomunikasi secara verbal dan emosional. Hal ini masih memungkinkan untuk dilatih bermasyarakat dan mempunyai kesempatan yang cukup baik bila diberikan pendidikan khusus yang dirancang secara khusus.

Sekolah umum/penyelenggara pendidikan inklusif berperan antara lain (1) memahami tingkat kemampuan anak autis yang akan dilayani di sekolah tersebut; (2) bekerja sama dengan orang tua dalam mempersiapkan layanan anak yang akan diterima di sekolah tersebut; dan (3) bekerja sama dengan tenaga profesional yang ada di pusat-pusat layanan autis dalam mempersiapkan anak selama mengikuti pendidikan transisi dan setelah diterima di sekolah tersebut (Mudjito, dkk., 2914: 80-81)

Berdasarkan analisis tersebut berarti Afa memerlukan sarana pembelajaran yang menarik perhatiannya. Harapannya, Afa dapat berlatih bersosial, yaitu dengan bermain bersama, tidak merasa terganggu oleh temannya, yang mana permainan tersebut juga dapat meningkatkan kemampuannya dalam berpikir, sehingga prestasi akademiknya juga meningkat. Untuk itu perlu diciptakan sebuah media pembelajaran.

Media pembelajaran bisa diartikan sebagai wahana yang dimuati pesan yang akan disampaikan oleh guru dan dipelajari oleh peserta didik (Kurniawan; 2011:147). Media pembelajaran diperlukan di samping untuk wahana penyampaian materi pembelajaran juga untuk meningkatkan kejelasan pembahasan materi. Selain itu, juga untuk memotivasi belajar peserta didik. Makin abstrak materi pembelajaran (berupa data dan informasi dalam bentuk simbol, angka, tulisan dan lisan), makin penting kehadiran media teramati atau tertangkap oleh pancaindera. Dengan demikian, kualitas belajar peserta didik akan semakin berkualitas. 
Kurniawan mengungkapkan bahwa sejumlah hal yang menjadi dasar pertimbangan pemilihan media pembelajaran, yaitu (a) sesuai dengan tujuan pembelajaran yang akan dicapai; (b) selaras dengan sifat materi yang akan dipelajari; (c) sesuai dengan tarap perkembangan kemampuan berpikir dan jumlah anak; (d) kemudahan untuk memperoleh media; (e) ketersediaan waktu untuk penggunaan media; dan (f) keterampilan guru dalam menggunakan media. Modus penggunaan media dalam pembelajaran berkaitan erat dengan pendekatan, strategi, dan metode pembelajaran yang digunakan. Oleh karena itu, ada sebagian ahli yang menyatakan bahwa media itu merupakan bagian dari metode, cara yang digunakan untuk mencapai tujuan pembelajaran. Ada beberapa modus penggunaan media dalam pembelajaran.

Narwanti; (2010: 37) menyimpulkan bahwa media pembel-ajaran merupakan wadah dari pesan, materi yang ingin disampaikan adalah pesan pembelajaran, tujuan yang ingin dicapai ialah proses pembelajaran. Secara umum, manfaat media pembelajaran adalah memperlancar interaksi antara guru dengan peserta didik sehingga kegiatan pembelajaran lebih efektif dan efisien. Secara khusus manfaat media dijabarkan oleh Narwanti (2010: 47) adalah (a) penyampaian materi pembelajaran dapat diseragamkan; (b) proses pembelajaran menjadi lebih jelas dan menarik; (c) proses pembelajaran menjadi lebih interaktif; (d) efisien dalam waktu dan tenaga; (e) meningkatkan kualitas hasil belajar peserta didik; (f) media memungkinkan proses belajar dapat dilakukan di mana saja dan kapan saja; (g) media dapat menumbuhkan sikap positif peserta didik terhadap materi dan proses belajar; dan (h) mengubah peran guru ke arah yang lebih positif dan produktif.

Mencermati keadaan dan kebutuhan Afa dan juga memperhatikan peserta didik reguler, penulis ciptakan sarana pembelajaran berupa media pembelajaran yang penulis beri nama "Menara Roda". Menara roda adalah sebuah media pembelajaran yang dirancang untuk anak berkebutuhan khusus dalam usaha untuk menarik perhatian agar tertarik pada pembelajaran. Apa pun pembelajarannya, menara roda dapat dimodifikasi. Dalam inovasi ini menara roda dirancang untuk kondisi khusus pada anak autis di Sekolah Dasar Negeri Tunjung 1 agar dapat bermain bersama dengan anak-anak reguler. Ini dikembangkan karena selama ini anak autis ini tidak mau 
bermain dengan temannya di sekolah. Dengan alat ini harapannya dia lebih nyaman dengan kesendiriannya, dapat benar-benar bermanfaat secara efektif dan memiliki dampak pengiring (nuturn efek) yang baik. Dengan media ini Afa dapat berlatih bersosial yaitu melalui bermain bersama anak reguler tanpa harus merasa terganggu, dapat menjalin komunikasi secara verbal, dan dapat mengendalikan emosionalnya. Penggunaan media ini memiliki dampak pengiring bagi Afa sendiri dan peserta didik reguler lainnya yaitu dapat peningkatan kemampuan berpikir yang ditandai dengan pemahaman bangun datar dan pola bilangan.

Hasil penelitian yang relevan antara lain: (1) Meningkaatkan Rentang Perhatian Anak Autis dalam Pembelajaran Pengenalan Hurufoleh Titisa Ballerina dari Universitas Sarjanawiyata Taman peserta didik, yang menyatakan bahwa anak autis memerlukan metode belajar sesuai dengan minatnya. Oleh sebab itu diperlukan asesmen terlebih dahulu untuk mengetahui minat, kelebihan, kekurangan, dan karakter lainnya. Hal tersebut berguna untuk menentukan metode pembelajaran yang efektif untuk anak autis. Selain itu kerja sama antarguru pembimbing, dan orang tua memiliki peran penting dalam proses pembelajaran anak autis; (2) Adaptasi Media Pembelajaran Gambar untuk Meningkatkan Aktifitas Belajar Anak Autis, oleh Pamuji, jurusan Pendidikan Luar Biasa Fakultas Pendidikan Unesa. Hasil Penelitian Pamuji menyatakan bahwa di lapangan anak autis dipahami sebagai anak yang bertipe belajar visual. Anak ini dapat memahami informasi, berbuat dan mengerjakan sesuatu seperti yang dilihatnya. Di samping itu, anak autis tertarik pada obyek berwarna, berbentuk, dan bertekstur tertentu. Ketertarikan tersebut dapat dimanfaatkan dalam kegiatan pembelajaran dan mengarahkan kegiatan belajar. Dalam hal ini peneliti ini membuat media gambar seperti apa dan bagaimana cara menggunakannya sehingga aktivitas belajar anak autis dapat meningkat.

Dari kedua peneliti tersebut di atas dapat dimaknai bahwa media merupakan hal penting dalam pembelajaran anak autis. Media dan metode menjadi satu kesatuan langkah yang terpisahkan dalam proses pembelajaran anak autis. Penulis sependapat dengan sebagian hasil penelitian tersebut. Namun penulis juga dapat mengkritisi dalam penelitian Titisa Ballerina 
yang menyatakan bahwa "anak autis memerlukan metode belajar sesuai dengan minatnya" itu benar tetapi jikalau itu dituruti terus, bagaimana dengan tuntutan kurikulum? Menurut penulis sesuai dengan prinsip alam takambang kita harus dapat membawa anak autis ke dunia secara umumnya. Dalam hasil penelitiannya, Pamuji menyatakan bahwa pandangan anak autis tertarik pada obyek berwarna, berbentuk, dan bertekstur tertentu, tidak seluruhnya benar. Buktinya anak autis bimbingan penulis tindak tertarik pada warna dan bentuk. Tetapi dia lebih tertarik pada gerak.

Terdapat kekuatan yang dimiliki oleh anak autis ini yakni kekuatan untuk selalu bergerak, tangannya ingin selalu bergerak beraktifitas. Melihat dari pola gerakannya, anak autis ini tampak memiliki energi yang lebih, sedangkan anak-anak reguler kurang dalam hal ini. Maka perlu dicarikan ruang atau sarana yang bisa menyatukan di antara keduanya. Artinya di sini, peserta didik autis tidak akan pergi jika didatangi oleh peserta didik reguler. Perlu diketahui bahwa anak autis ini lebih asyik dengan kesendirianya. Media yang diciptakan benar-benar membantu Afa (autis) dalam bersosial, tetapi juga bermanfaat bagi peserta didik reguler. Adalah tidak adil jika suatu media hanya berguna bagi satu orang saja, tetapi media yang baik itu dapat membantu semuanya. Manfaat media bagi anak-anak reguler dalam hal ini adalah peningkatan prestasi akademiknya karena dalam hal interaksi sosial tidak ada persoalan. Artinya, dengan menggunakan satu media, didapatkan dua kondisi (autis dan reguler) secara bersamaan, bahkan bisa lebih. Kondisi yang diharapkan antara lain peserta didik autis dan reguler dapat bersosial (bersatu) dan keduanya juga mendapatkan dampak pengiring yang baik.

Pada proses pembelajaran di kelas, anak autis belajar bersama-sama dengan anak reguler. Pertanyaan dan atau jawaban yang dilakukan oleh guru berlaku untuk semua peserta didik. Semua memiliki kesempatan dan hak serta kewajiban yang sama. Dalam hal menjawab pertanyaan, peserta didik autis dapat menjawab pertanyaan guru saat pembelajaran tersebut dengan dua, tiga atau lebih, yang dapat didengar oleh peserta didik reguler lainnya. Dapat juga peserta didik reguler yang menjawab pertanyaan guru dan didengar oleh peserta didik autis karena di antara keduanya jaraknya sangat dekat serta saling melihat. 
Berdasarkan ide penulis dan didukung oleh beberapa teori, serta mencermati hasil penelitian terdahulu tentang pembuatan media pembelajaran. Yang mana media ini digunakan untuk membantu pembelajaran mengatasi gangguan sosial pada anak autis di Sekolah Dasar Negeri Tunjung 1 khususnya kepada Afa. Selain itu, penggunaan alat ini juga dapat meningkatkan pola pikir kritis, kreatifnya sebagai dampak pengiring (nuturn efek) yang ditandai pemahaman materi bangun ruang sederhana, dan pola atau deret urut dari suatu bilangan dalam matematika. Dari sinilah tercetus ide membuat media pembelajaran "Menara roda" ini. Keunikan media ini adalah dari media ini selain dapat memberdayakan antara anak autis dengan anakanak reguler, fakta lain yang muncul adalah dapat menunjukkan bentuk bangun datar (persegi, segitiga, persegi panjang) dari yang bentuknya besar ke yang kecil, serta dari bentuk-bentuk tersebut muncul sebuah pola bilangan dari besar ke bilangan kecil. Dari pola bilangan tersebut dapat ditemukan pola bilangan dari kecil ke besar

Permasalahannya adalah apakah media "Menara Roda" dapat memberdayakan peserta didik berkebutuhan khusus k autis, dengan anak reguler dan apakah dampak pengiring (nuturn efek) terhadap peningkatan prestasi akademik anak autis dan anak reguler?

Tujuan inovasi pembelajaran menggunakan media "Menara Roda" ini adalah memberdayakan peserta didik berkebutuhan khusus anak autis dengan anak reguler dalam permainan dan mengetahui dampak pengiring (nuturn efek) terhadap peningkatkan prestasi akademik anak autis dan anak reguler.

\section{B. Metode}

Metode Media pembelajaran "Menara roda" ini dirancang untuk digunakan secara bersama-sama,tanpa ada yang merasa terganggu, tetapi saling mendukung, menciptakan suasana riang, mewujudkan persatuan, kebersamaan, tetapi juga dapat digunakan untuk pembelajaran secara individu, jika tidak ada temannya. Adapun rancangan karya inovasi pembelajaran media "Menara roda" ini adalah seperti gambar di samping. 


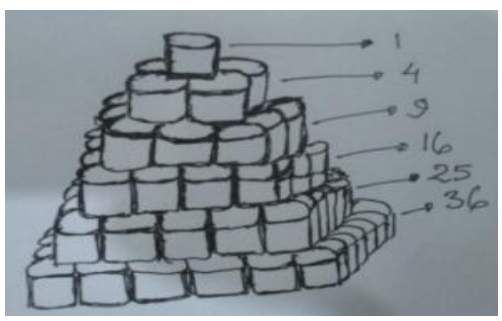

Untuk mendapatkan karya yang sesuai dengan rancangan diperlukan alat dan bahan untuk mewujudkannya. Alat yang digunakan antara lain: gergaji, bor, palu, paku, pisau belati pisau kerat/sabit, kuas, dan ampelas (kertas gosok). Bahan yang diperlukan antara lain: kayu bulat (tongkat/ ranting/ batang kayu), bambu, lem kayu (rajawali/ fox/ aibon dan sejenisnya), cat, teriplek/papan, dan gabus (sterofom tebal) dan kayu reng. Seperti tampak pada gambar di samping.

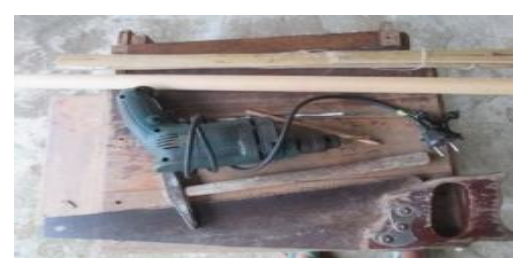

Gergaji untuk memotong-motong kayu tongkat (dapat dibeli di toko penjual alat-alat Pramuka) menjadi roda-roda. Kayu tongkat dipilih karena ukuran besarnya sama. Bor untuk melubangi potongan kayu yang telah menjadi roda dan papan triplek sesuai dengan pola yang diinginkan. Pisau/ sabit digunakan untuk meraut, memotong bambu dan memotong gabus/ sterofom. Bambu sebagai as pada roda. Bambu diraut untuk as tersebut. Palu dan paku untuk memaku papan triplek dengan kayu reng. Kertas gosok untuk menghaluskan papan triplek dan kayu reng. Kuas untuk mengecat.

Kayu bulat sebagai bahan roda-roda, lem untuk perekat bagian dalam lobang dengan bambu, cat untuk mewarnai roda-roda, bambu untuk as roda, kayu triplek sebagai papan untuk menancapkan roda, sterofom digunakan untuk melapisi papan bagian dalam. 
Menara roda dibuat dengan langkah-langkah sebagai berikut. Dibuat ukuran panjang dengan tujuan ukuran ini agar sama panjangnya potongan kayu, tanpa harus selalu mengukur. Seperti tampak pada gambar di samping.
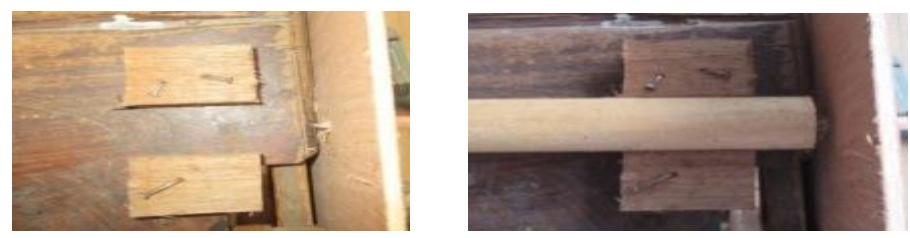

Kayu bulat/ tongkat diletakkan pada ukuran lalu dipotong. Didorong sesuai ukuran laludipotong lagi sampai menjadi banyak roda lebih dari 300 buah. Lebih banyak lebih baik. Seperti gambar di samping. Kayu yang sudah dipotong menjadi roda selanjutnya dilubangi bangian tengahnya, kemudian lubang tersebut diberi lem kayu lalu dimasuki rautan bambu.
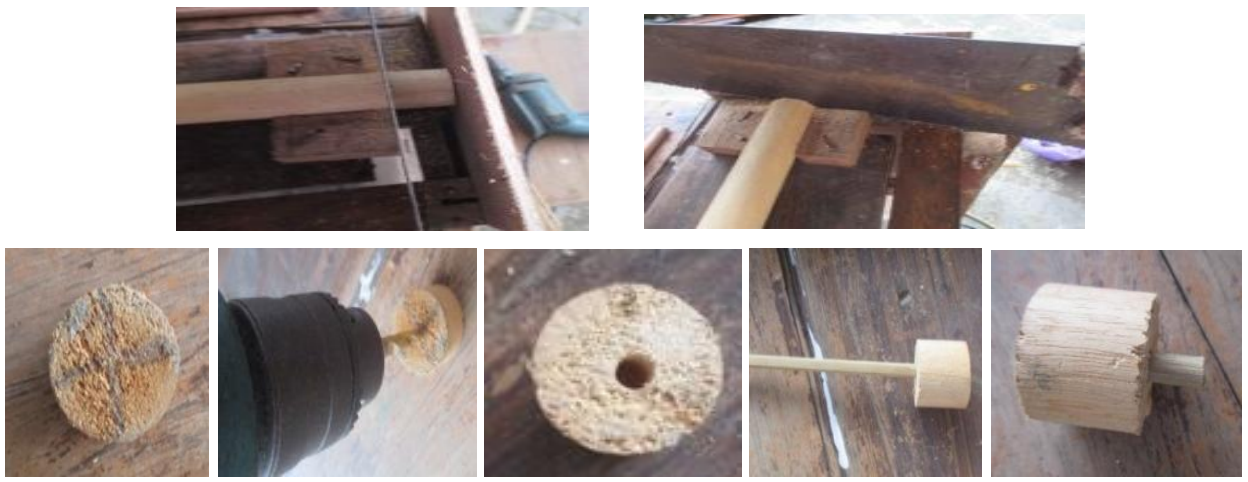

Pada tahap ini dapat dilakukan pengecatan. Pengecatan juga dapat dilakukan pada saat kayu tongkat belum dipotong-potong. Setelah dicat dengan berbagai warna dan dirapikan rautan bambunya hasilnya nampak seperti gambar berikut di bawah ini dan siap pakai.
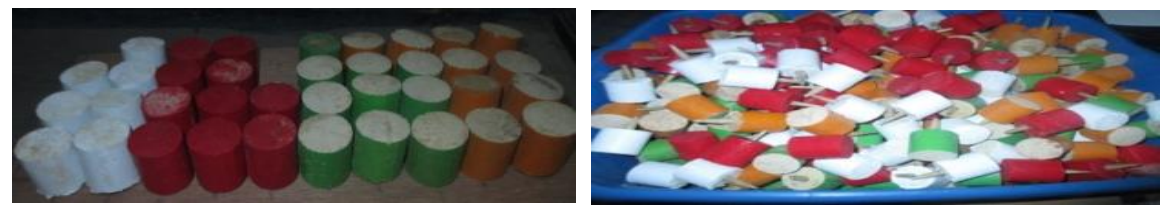

Potong triplek sesuai kebutuhan. Kemudian dibuat lubang-lubang sesuai dengan bangun datar yang akan dibuat menara. Misalnya persegi, persegi panjang, dan segitiga. Setelah selesai bagian bawah dilandasi 
dengan kayu reng yang dipotong dijadikan bingkai, kemudian dimasukkan storofom di dalam agar roda yang ditancapkan tidak bergerak. Seperti gambar berikut, papan menara roda siap pakai.
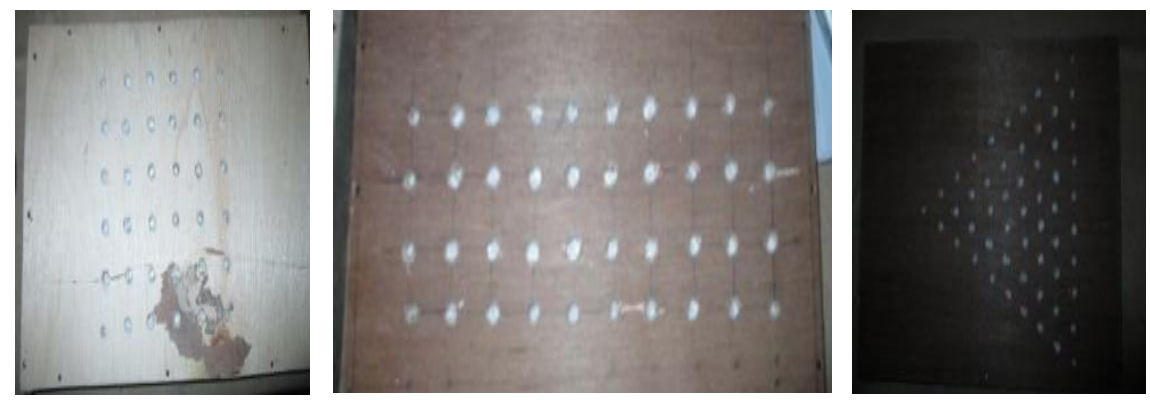

Dalam proses pembelajaran guru perlu memiliki lembar pengamatan untuk mengetahui ketertarikan anak autis berupa daftar pernyataan yang dapat diisi dengan ceklis. Seperti tampak pada tabel berikut.

Tabel 1. Lembar Pengamatan Demontrasi.

\begin{tabular}{|c|c|c|c|c|c|c|}
\hline \multirow{2}{*}{ No } & \multirow[b]{2}{*}{ Aspek } & \multicolumn{2}{|c|}{ Anak Autis } & \multicolumn{2}{|c|}{ Anak Reguler } & \multirow{2}{*}{ Catatan } \\
\hline & & Ya & Tidak & $\mathrm{Ya}$ & Tidak & \\
\hline 1 & $\begin{array}{l}\text { Terdapat gerak anggota tubuh yang } \\
\text { terindikasi mengganggu. }\end{array}$ & & & & & \\
\hline 2 & Tampak raut wajah kecewa. & & & & & \\
\hline 3 & Tampak raut wajah marah & & & & & \\
\hline 4 & Terdapat bullying & & & & & \\
\hline 5 & Terdapat gurauan & & & & & \\
\hline 6 & $\begin{array}{l}\text { Usaha merebut roda yang sudah } \\
\text { dipegang temannya. }\end{array}$ & & & & & \\
\hline 7 & Tampak kerja sama & & & & & \\
\hline 8 & Tampak wajah puas & & & & & \\
\hline
\end{tabular}

Selain lembar pengamatan guru juga harus memiliki lembar kerja peserta didik seperti tabel berikut.

Tabel 2. Isian Menara Roda

\begin{tabular}{|c|c|c|c|}
\hline \multirow{2}{*}{ Posisi } & Persegi & Persegi panjang & Segi tiga sama sisi \\
\cline { 2 - 4 } & Jumlah Roda & Jumlah Roda & Jumlah Roda \\
\hline I & 1 & & \\
\hline II & & & \\
\hline III & & & \\
\hline IV & & & \\
\hline V & & & \\
\hline dst & & & \\
\hline
\end{tabular}




\section{Hasil dan Pembahasan}

Aplikasi praktis dalam pembelajaran media pembelajaran Menara roda dalam rangka memberdayakan anak autis dan meningkatkan kemampuan akademik peserta didik autis dan anak reguler terutama pada materi bangun datar dan pola bilangan, hasil dan pembahasannya sebagai berikut.

\section{Hasil}

Peserta didik autis (Afa) ini kegemarannya bermain di kantor guru. Di kantor guru ini dia banyak bergerak ke sana kemari sambil memukul mukul meja atau tumpukan buku-buku. Pada saat bermain di kantor guru ini alat permainan "Menara Roda" ini diperkenalkan. Dengan cara memanggil dia. Bang biasa dia dipanggilnya. "Bang main sama Bapak, yok." Guru mendatanginya sambil membawa alat permainan menara roda. Kemudian guru meminta dia untuk memasukkan roda-roda ini pada lobang-lobang yang telah disediakan. Guru juga ikut bermain. Ternyata Afa tertarik. Dia bermain sambil menggumam dengan bahasa yang tidak jelas, dan berhasil menyusun roda-roda menjadi menara.
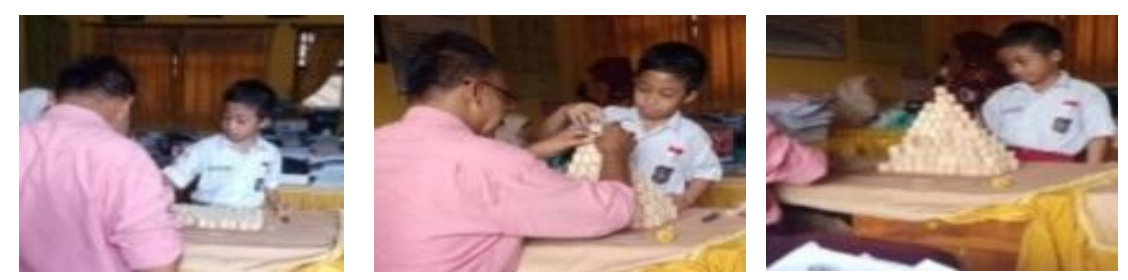

a) Setelah berhasil, guru memberi penghargaan dengan cara tos dua tangan. Kemudian guru membongkar susunan menara tersebut, dan mengajak menyusun lagi. Untuk menguji respon dia, guru memanggil temannya yang sedang lewat untuk menonton Afa menyusun roda-roda. Ternyata dia tidak merasa terganggu. Dia tetap asyik bermain bersama guru. Seperti gambar di samping.
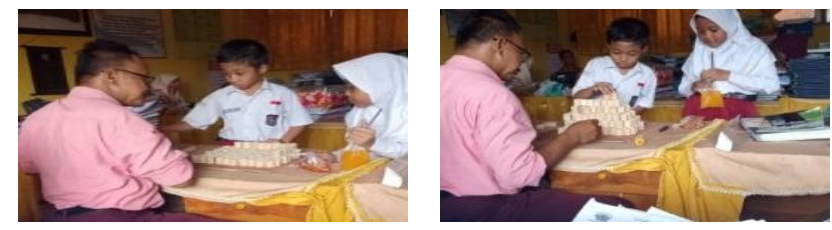
b) Setelah Afa ternyata tidak merasa terganggu dengan kehadiran temannya, guru membongkar lagi menara yang telah tersusun, kemudian mengajaknya untuk bermain lagi, namun guru berkata kepada Afa dengan kalimat, "Gak asyik kalau mainnya sendirian, ajak dia main yok, boleh." Ternyata Afa diam tidak menjawab, namun tampak melihat temannya itu. Kemudian guru berkata, "Yok kita mulai." Guru bersama Afa bermain, selanjutnya guru berkata kepada temannya itu dengan perkataan, "Tolongin dong, biar cepat!" Kata tolongin dipilih agar Afa tidak merasa diganggu, tetapi justru dibantu. Hasilnya, ternyata dia tidak merasa terganggu.
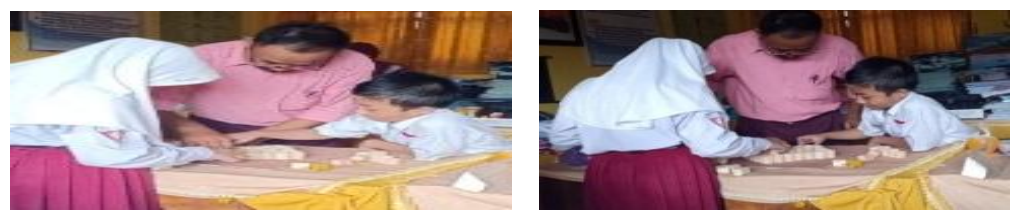

c) Pada kesempatan berikutnya, media dibawa ke dalam kelas. Guru tidak langsung mengajak belajar, tetapi mencari momen-momen tertentu jika Afa sedang tidak semangat. Hal ini dilakukan karena media ini bertujuan untuk memberdayakan peserta didik autis dengan peserta didik reguler. Jika masih ada kebersamaan di antara mereka, media ini belum digunakan. Guru terus memotivasi dan melanjutkan kebersamaan mereka, serta mendorong mereka agar tetap bersama.

d) Selanjutnya jika Afa sedang pada saat emosi tidak stabil, dengan cepat guru, mengalihkan perhatian Afa pada media ini. Dalam tahap ini, Afa diajak ke permainan ini, sedangkan temannya menonton dahulu. Jika Afa sudah sampai pada tahap asyik/ menikmati, guru memberikan salah satu papan permainan kepada temannya, kemudian temannya/ peserta didik reguler akan mencoba permainan "Menara Roda" ini. Sampai peserta didik reguler dapat menyusun roda-roda menjadi menara.
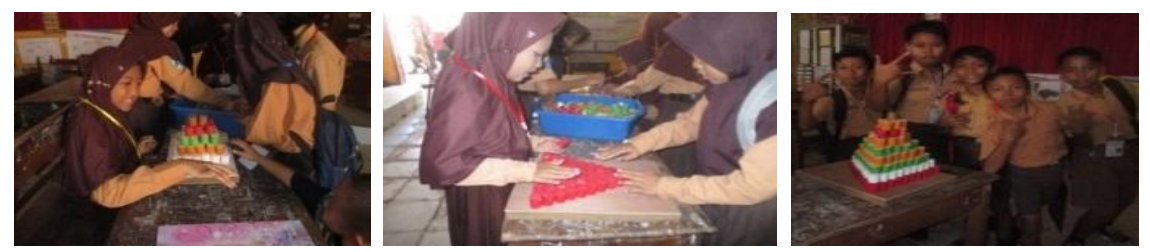
e) Jika mereka semua sudah dapat menyusun roda-roda menjadi menara, kemudian guru mengajak semua peserta didik bermain termasuk dianataranya Afa. Tampak seperti gambar berikut.
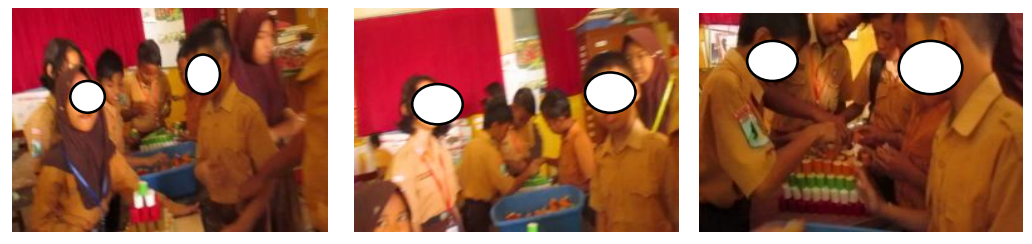

f) Setelah tahap permainan ini, karena mereka nampaknya sudah mulai menikmati permainan ini guru membawa permaianan ke tahap peningkatan akademik. Peserta didik diminta mengamati dengan seksama menara roda yang telah dibuatnya. Guru memberikan lembar kerja. Peserta didik diminta menghitung banyaknya roda pada posisi paling atas, seperti gambar berikut.

\begin{tabular}{|c|c|c|}
\hline \multirow{2}{*}{} \\
\cline { 2 - 3 }
\end{tabular}

g) Peserta didik mengambil roda paling atas sehingga tampak banyaknya roda pada posisi II, lalu menghitungnya dan memasukkan ke dalam tabel seperti gambar berikut.

\begin{tabular}{|c|c|c|}
\hline \\
\cline { 2 - 3 }
\end{tabular}

h) Peserta didik mengambil roda pada posisi II sehingga tampak banyaknya roda pada posisi III, lalu menghitungnya dan memasukkan ke dalam tabel seperti gambar berikut. 


\begin{tabular}{|c|c|c|}
\hline \multirow{2}{*}{} \\
\cline { 2 - 3 }
\end{tabular}

i) Peserta didik mengambil roda pada posisi III sehingga nampak banyaknya roda pada posisi IV, lalu menghitungnya dan memasukkan ke dalam tabel seperti gambar berikut.

\begin{tabular}{|c|c|c|}
\hline \\
\cline { 2 - 3 }
\end{tabular}

j) Peserta didik mengambil roda pada posisi III sehingga nampak banyaknya roda pada posisi IV, lalu menghitungnya dan memasukkan ke dalam tabel seperti gambar berikut

\begin{tabular}{|c|c|c|}
\hline \\
\cline { 2 - 3 }
\end{tabular}

k) Peserta didik mengambil roda pada posisi IV sehingga nampak banyaknya roda pada posisi $\mathrm{V}$, lalu menghitungnya dan memasukkan ke dalam tabel seperti gambar berikut.

\begin{tabular}{|c|c|c|}
\hline \multirow{2}{*}{} \\
\cline { 2 - 3 }
\end{tabular}


1) Peserta didik mengambil roda pada posisi $V$ sehingga nampak banyaknya roda pada posisi VI, lalu menghitungnya dan memasukkan ke dalam tabel seperti gambar berikut.

\begin{tabular}{|c|c|c|}
\hline \multirow{2}{*}{} \\
\cline { 2 - 3 }
\end{tabular}

m) Setelah peserta didik selesai membongkar menara roda dari posisi I sampai posisi akhir, setiap kelompok, peserta didik diminta untuk menambah posisi-posisi pada tabelnya sampai seluruh tabel terisi dan peserta didik mengisi jumlah rodanya dengan cara peserta didik mengamati terlebih dahulu pola bilangannya.

n) Peserta didik dalam kelompok menukarkan papan menara rodanya kepada kelompok lain, kemudian menyusun rodarodanya sampai menjadi menara kemudian peserta didik melakukan kegiatan seperti kegiatan (g) sampai (m) di atas seperti nampak pada gambar di atas.

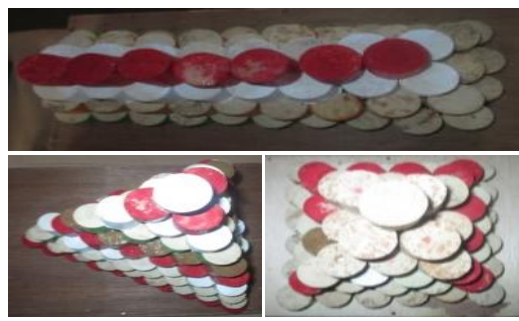

Data hasil aplikasi praktis diperoleh dari hasil pengamatan dan data pada lembar kerja peserta didik. Pengamatan untuk mengetahui dampak dari permainan "Menara Roda" pada anak autis maupun anak reguler. Yang mana bahwa tujuannya adalah memberdayakan anak autis dengan anak reguler beserta dampaknya.

Data peningkatan kemampuan akademik diperoleh pada isian lembar kerja yaitu tentang pola bilangan yang dihasilkan dari demontrasi 
permainan "Menara Roda" pada papan bidang datar yang telah disiapkan. Data hasil aplikasi praktis inovasi sebagai berikut.

Tabel 3. Tabel Pengamatan Demontrasi.

\begin{tabular}{|c|c|c|c|c|c|c|}
\hline \multirow{2}{*}{ No } & \multirow{2}{*}{ Aspek } & \multicolumn{2}{|c|}{ Anak Autis } & \multicolumn{2}{|c|}{ Anak Reguler } & \multirow{2}{*}{ Catatan } \\
\hline & & $\mathrm{Ya}$ & Tidak & $\mathrm{Ya}$ & Tidak & \\
\hline 1 & $\begin{array}{l}\text { Terdapat gerak anggota tubuh yang } \\
\text { terindikasi mengganggu. }\end{array}$ & & $\mathrm{v}$ & & $\mathrm{v}$ & \\
\hline 2 & Tampak raut wajah kecewa. & & $\mathrm{V}$ & & $\mathrm{V}$ & \\
\hline 3 & Tampak raut wajah marah & & $\mathrm{V}$ & & $\mathrm{V}$ & \\
\hline 4 & Terdapat bullying & & $\mathrm{V}$ & & $\mathrm{v}$ & \\
\hline 5 & Terdapat gurauan & & $\mathrm{V}$ & $\mathrm{V}$ & & \\
\hline 6 & $\begin{array}{l}\text { Usaha merebut roda yang sudah dipegang } \\
\text { temannya. }\end{array}$ & & $\mathrm{v}$ & & $\mathrm{V}$ & \\
\hline 7 & Tampak kerja sama & $\mathrm{V}$ & & $\mathrm{v}$ & & \\
\hline 8 & Tampak wajah puas & $\mathrm{v}$ & & $\mathrm{V}$ & & \\
\hline
\end{tabular}

Keterangan: Aspek

1) Terdapat gerak anggota tubuh yang terindikasi mengganggu misalnya: mencubit, menabok, menendang, menyenggolkan bandannya, menghadang.

2) Tampak raut wajah kecewa dapat dilihat melelui gestur.

3) Tampak raut wajah marah dapat dilihat dari gestur wajah dan sikap/ ucapan.

4) Terdapat bulying misalnya saling mengolok-olok.

5) Terdapat gurauan dapat dilihat dari tingkah, misalnya joget, ucapan.

6) Usaha merebut roda yang sudah dipegang temannya misalnya merebut yang suah dipegang, mendahului roda yang akan diambil kawan.

7) Tampak kerjasama tampak dari saat mereka bermain mereka akan mengisi yang masih kosong, tidak mengambil yang sudah diisi.

8) Tampak wajah puas dapat dilihat dari gestur gerak tubuh dan sejenisnya.

Hasil pembelajaran dalam hal ini adalah peningkatan prestasi akademik bagi anak autis dan anak reguler. Penilaian hasil belajar ini meliputi pola bilangan pada "Menara Roda" : I= Persegi, II = Persegi panjang, dan III= Segi tiga sama sisi. Masing-masing menara terdiri dari 10 posisi. Hasil pembelajaran nampak pada tabel berikut. 
Tabel 4. Tabel Hasil Belajar

\begin{tabular}{|c|c|c|c|c|c|c|}
\hline \multirow{2}{*}{ No } & \multirow{2}{*}{ Nama Peserta didik } & \multicolumn{3}{|c|}{ Menara Roda } & \multirow{2}{*}{ Jumlah } & \multirow{2}{*}{ Nilai Akhir } \\
\hline & & $\mathrm{I}$ & II & III & & \\
\hline 1 & Achmad Fayedh Abram & 10 & 10 & 10 & 30 & 10,0 \\
\hline 2 & Alfredho Renaldho & 10 & 10 & 10 & 30 & 10,0 \\
\hline 3 & Alia Ramadhani & 10 & 7 & 10 & 27 & 9,0 \\
\hline 4 & Alin Nur Laila & 10 & 8 & 10 & 28 & 9,3 \\
\hline 5 & Anggun Bunga Lestari & 9 & 10 & 8 & 27 & 9,0 \\
\hline 6 & Aurora Septiana Putr & 10 & 8 & 9 & 27 & 9,0 \\
\hline 7 & Balqist Sofia Saleh & 8 & 10 & 10 & 28 & 9,3 \\
\hline 8 & Dalil El Falihin & 9 & 9 & 7 & 25 & 8,3 \\
\hline 9 & Debbi Irawan & 10 & 10 & 6 & 26 & 8,7 \\
\hline 10 & Destin Aulia Nur H & 9 & 8 & 10 & 27 & 9,0 \\
\hline 11 & Dorotun Navisa & 9 & 10 & 10 & 29 & 9,7 \\
\hline 12 & Dzikrina Ika S & 10 & 10 & 10 & 30 & 10,0 \\
\hline 13 & Gegeng Lamora F & 9 & 10 & 8 & 27 & 9,0 \\
\hline 14 & Gustri Ridwan Haikal & 10 & 10 & 10 & 30 & 10,0 \\
\hline 15 & Imron Rosadi & 7 & 10 & 7 & 24 & 8,0 \\
\hline 16 & Ivan Setiawan & 10 & 8 & 10 & 28 & 9,3 \\
\hline 17 & Khoirun Nissak Kaina & 8 & 10 & 9 & 27 & 9,0 \\
\hline 18 & Mauidhatul Hasanah & 8 & 9 & 10 & 27 & 9,0 \\
\hline 19 & Mohamad Yusuf A & 10 & 10 & 10 & 30 & 10,0 \\
\hline 20 & Mohammad Haikal & 7 & 10 & 7 & 24 & 8,0 \\
\hline 25 & Sulthon Septya Mara & 10 & 10 & 10 & 30 & 10,0 \\
\hline 26 & Tarissa Amelia & 10 & 10 & 8 & 28 & 9,3 \\
\hline \multirow[t]{3}{*}{27} & Zulkifli Andani & 10 & 10 & 10 & 30 & 10,0 \\
\hline & Jumlah nilai & 246 & 254 & 247 & & \\
\hline & Rata-Rata Kelas & 9,11 & 9,41 & 9,15 & & \\
\hline
\end{tabular}

Selanjutnya data hasil pengamatan pada proses pembelajaran maupun data hasil pembelajaran yang berupa lembar pengamatan dan isian lembar kerja peserta didik, dianalisis untuk menentukan kesimpulan apakah terdapat hasil sesuai dengan tujuan. Analisis hasil aplikasi praktis inovasi pembelajaran di bahas pada subbab berikut.

\section{Pembahasan}

Mencermati data pengamatan seperti pada tabel 3. Tabel pengamatan demontrasi, hasil menunjukkan: tidak terdapat gerak anggota tubuh yang terindikasi mengganggu, tidak tampak raut wajah kekecewaan, tidak tampak raut wajah marah, tidak terdapat bullying, tidak tampak usaha merebut roda yang sudah dipegang temannya, tampak kerja sama dan 
tampak wajah puas, bersama-sama. Antara anak autis dan anak reguler sama-sama asyik bermain dengan alat yang sama. Hanya satu perbedaan yaitu tidak ada gurauan pada diri Afa, sedangkan lainnya saling bergurau. Salah satu tanda keakraban adalah bercanda atau bergurau.

Afa anak yang memiliki gangguan dan keterlambatan dalam bidang kognitif, komunikasi, ketertarikan pada interaksi sosial dan perilakunya. Depdiknas (2002) menyatakan bahwa autisme adalah suatu perkembangan yang kompleks menyangkut komunikasi, interaksi sosial, dan aktivitas imajinasi. Karakteristik khusus autisme menurut Worth (2005: 1) antara lain sangat suka menyendiri dan miskin kemampuan respon sosial yang berlebihan, terhadap suatu rutinitas atau pola tetap, memiliki ingatan yang kuat, dan perkembangan bahasa yang lambat. Kewajiban guru bertanggungjawab dalam memupuk persahabatan dan memungkinkan terjalinnya hubungan sebagai usaha untuk mengurangi kerentanan murid autis.

Melihat secara seksama pada proses pembelajaran yang berlangsung dan data-data hasil pengamatan dapat disimpulkan bahwa "Menara Roda" dapat memberdayakan anak autis dengan anak reguler di UPTD SD Negeri Tunjung 1. Artinya peserta didik autis dan peserta didik regular dapat bersatu bersama-sama, terjalin interaksi sosial yang baik. Selama pembelajaran berlangsung Afa dapat fokus melakukan kegiatan bersama-sama temannya. Tidak melakukan kegiatan negatif seperti telah diterangkan di muka.

Data hasil pembelajaran pada tabel 4 di atas diolah menjadi seperti tabel 5 berikut.

Tabel 5. Olah Data Nilai Hasil Pembelajaran

\begin{tabular}{|c|l|c|c|c|c|c|}
\hline \multirow{2}{*}{ No. } & \multirow{2}{*}{ Nama Peserta didik } & \multicolumn{3}{|c|}{ Menara Roda } & \multirow{2}{*}{ Jumlah } & \multirow{2}{*}{ Nilai Akhir } \\
\cline { 3 - 6 } & & I & II & III & & \\
\hline 1 & Achmad Fayedh Abram & 10 & 10 & 10 & 30 & 10,0 \\
\hline 2 & Alfredho Renaldho & 10 & 10 & 10 & 30 & 10,0 \\
\hline 27 & Zulkifli Andani & 10 & 10 & 10 & 30 & 10,0 \\
\hline & Jumlah nilai & 246 & 254 & 247 & & \\
\hline & Rata-Rata Kelas & 9,11 & 9,41 & 9,15 & & \\
\hline
\end{tabular}


Afa masuk dalam kategori fungsi kecerdasan menengah. Hal ini masih memungkinkan untuk dilatih bermasyarakat dan mempunyai kesempatan yang cukup baik bila diberikan pendidikan khusus yang dirancang secara khusus. Sekolah umum/ penyelenggara pendidikan inklusif berperan antara lain (1) memahami tingkat kemampuan anak autis yang akan dilayani di sekolah tersebut; (2) bekerja sama dengan orang tua dalam mepersiapkan layanan anak yang akan diterima di sekolag tersebut; dan (3) bekerjasama dengan tenaga profesional yang ada di pusat-pusat layanan autis dalam mempersiapkan anak selama mengikuti pendidikan transisi dan setelah diterima di sekolah tersebut (Mudjito. Dkk., 2914: 80-81). Afa memerlukan sarana pembelajaran yang menarik perhatiannya, yang mana media tersebut juga dapat meningkatkan kemampuannya dalam berpikir, sehingga prestasi akademiknya juga meningkat.

Melihat data-data di atas dapat diinterpretasikan bahwa menara roda dapat meningkatkan kemampuan akademik baik anak autis maupun anak reguler. Hal ini dibuktikan dengan kemampuan rata-rata untuk pola bilangan yang dihasilkan oleh menara persegi rata-rata kelasnya 9,11. Itu anak autis mendapatkan nilai sempurna (10). Kemampuan rata-rata untuk pola bilangan yang dihasilkan oleh menara persegi panjang rata-rata kelasnya mencapai 9,41. Anak autis mendapatkan nilai sempurna (10). Demikian juga untuk nilai rata-rata peserta didik dalam pola bilangan yang dihasilkan oleh menara roda segitiga sama sisi sebesar 9,15. Peserta didik autis juga mendapatkan nilai sempurna (10)

Sejak tahun 2014 KKG Gugus sekolah 3 Kecamatan Burneh, menjadikan seminar ilmiah hasil inovasi pembelajaran, penelitian tindakan kelas, penelitian tindakan sekolah, dan gagasan konseptual, menjadi egenda rutin setiap tahun. Hal ini untuk mendorong dan memberikan kesempatan kepada anggota KKG untuk mempublikasikan hasil penelitian dan atau inovasi pembelajarannya. Inovasi pembelajaran yang penulis susun ini juga mendapatkan kesempatan untuk diseminarkan pada tanggal $11 \mathrm{Mei}$ 2019 di SDN Tunjung 2.

Tanggapan teman-teman masih ada kekurangan karena peserta didik autisnya hanya 1 orang, sehingga menurut teman-teman hasilnya juga harus diujikan pada sekolah yang peserta didik autisnya banyak. 
Penulis menyadari karena teman-teman belum begitu paham tetang sekolah inklusif, karena memang hanya satu-satunya sekolah di Kecamatan Burneh ini yang menyelenggarakan pendidikan inklusif, serta sekolah pertama di antara tiga sekolah penyelenggara inklusif di Kabupaten Bangkalan.

Tanggapan yang lain teman sangat mengapresiasi karya penulis terhadap konsep ini karena dengan media "Menara roda" ini antara peserta didik autis dan peserta didik reguler dapat bermain bersama, serta dapat digunakan untuk mengajarkan pola bilangan, yang mana pola bilangan ini jarang diajarkan.

\section{Penutup}

Menara roda sebagai media pembelajaran dapat memberdayakan anak autis dengan anak reguler. Selama proses pembelajaran berlangsung tidak muncul gerak anggota tubuh yang terindikasi mengganggu, tidak tampak raut wajah kekecewaan, marah, tidak terdapat bullying, tidak tampak usaha merebut roda yang sudah dipegang temannya, tampak kerja sama dan tampak wajah puas, secara bersama-sama. Baikanak autis dan anak reguler sama-sama asyik bermain dengan alat yang sama. Satu perbedaan yaitu tidak ada gurauan (yang menunjukkan perilaku anak-anak gembira) pada diri Afa. Dalam hal ini tampaknya sulit untuk dimunculkan, sedangkan yang lain saling bergurau. Salah satu tanda keakraban adalah dalam bentuk perayaan keberhasilan bersama, yakni bertepuk tangan, tos, dan jogetjoget khas keriangan anak-anak. Penggunaan menara roda sebagai media pembelajaran memiliki dampak pengiring (nuturn efek) berupa peningkatkan prestasi akademik anak autis dan anak reguler. Kemampuan rata-rata pola bilangan yang dihasilkan oleh menara persegi, menara persegi panjang, dan menara segitiga sama sisi, rata-rata kelasnya antara 9,11 sampai dengan 10,00. Itu anak autis mendapatkan nilai sempurna (10). Hal ini menunjukkan juga bahwa media ini dapat meningkatkan pola pikir kritis, kreatifnya, yang ditandai pemahaman materi bangun ruang sederhana, dan pola atau deret urut dari suatu bilangan dalam matematika.

Sebagai bahan penelitian ke depan, kepada teman sejawat, mari kita bersama menerima anak-anak yang berkebutuhan khusus di sekitar 
kita agar mereka juga dapat mengenyam pendidikan sama dengan anakanak lainnya. Bagi sejawat yang ingin menggunakan media ini diharapkan menyesuaikan dengan lingkungan dan mohon untuk disempurnakan. Pengelola pendidikan siap menerima anak bangsa tanpa membedakan status apapun sebagaimana amanat Undang-Undang Dasar 1945, karena pendidikan merupakan hak dasar warga negara tanpa terkecuali, dan juga penyelenggara pendidikan juga lebih banyak memberi motivasi kepada guru untuk selalu berkreatif dan menyediakan anggaran untuk kreatifitas guru. Sehingga guru berpacu demi anak-anak bangsa ini. Baiknya kita selalu berbincang-bincang tentang inovasi tanpa bosan, karena ternyata inovasi itu mengasyikkan, Stiekholder di daerah banyak memberi ruang kreativitas guna memberi cambuk bagi guru untuk kreatif.

\section{Ucapan Terimakasih}

Penulis menghaturkan banyak terima kasih kepada Kementerian Pendidikan dan kebudayaan, secara khusus Direktur Jenderal Guru dan Tenaga Kependidikan yang telah memberikan kesempatan, berinisiatif , mengadakan kegiatan yang mendorong kreativitas guru dalam pembelajaran, hingga terbitnya artikel karya tulis ini. Ucapan terima kasih pula disampaikan kepada Kepala sekolah, teman-teman guru, dan peserta didik UPTD SD Negeri Tunjung 1 Kecamatan Burneh yang telah memberikan dorongan semangat dalam inovasi pembelajaran ini.

\section{Daftar Referensi}

Ballerina, T (2016). INKLUSIF: Jurna of Disability Studies, Vol. 3, No 2, JuliDesember 2016, hal 245-266.

Brower, F. (2010). 100 Ide Membimbing Anak Autis, Jakarta; Erlangga.

Djahiri, A.K. (1996b). Menelusuri Dunia Afektif Pendidikan Nilai dan Moral, Bandung: Lab.Pengajaran PMP IKIP Bandung.

Kemendiknas. (2010). Permendiknas No. 70 tahun 2010 Tentang Pendidikan Iklusif

Kemendiknas. (2006). Model Pembelajaran dan Pendidikan Penyelenggaraan Pendidikan Inklusif. Jakarta: Direktorat Pembinaan SLB. 
Kurniawan, D, (2011), Pembelajaran Terpadu Teori, Praktek dan Penilaian. Bandung: Pustaka Cendekia Utama.

Mudjito, dkk. (2014). Layanan Pendidikan Transisi Anak Autis, Direktorat Pembinaan Pendidikan Khusus dan layanan khusus. Jakarta: Dirjenpendas Kemdikbud.

Narwanti. S. (2011). Pendidikan Karakter. Yogyakarta: Familia.

Pamuji, (2014), Jurnal Ortopedagogia, Volume 1 Nomor 2 Juli 2014; hal 117-127.

Satyadi, H. (2015). Spirit Media Pendidikan Khusus \& Pendidikan Layanan Khusus diterbitkan Direktorat Pembinaan Pendidikan Khusus dan Layanan Khusus (PPK-LK) edisi 73 tahun X 2015 hal. 11.

Suyanto. (2012). Pendidikan Karakter untuk Karakter Bangsa, Policy Brief Direktorat Jenderal Pendidikan Dasar, Kemdiknas Jakarta, http//:dikdas.kemdikbud.go.id. edisi 4 Juni/2012.

Tabrani ZA. (2014). Dasar-Dasar Metodologi Penelitian Kualitatif. Yogyakarta: Darussalam Publishing.

Widyawati, I. (2015), Spirit Media Pendidikan Khusus \& Pendidikan Layanan Khusus diterbitkan Direktorat Pembinaan Pendidikan Khusus dan Layanan Khusus (PPK-LK) edisi 73 tahun X 2015 hal. 11.

Worth, S. (2005). Autistic Spectrum Disorder. London: Continuum Internasional Publishing Group. 